\title{
Spiritual Care at The End Of Life: Western Views and Islamic Perspectives \\ Wafa' a Qasem Ahmad'
}

\begin{abstract}
The concept of spiritual and religious care, as core components of palliative care for patients at end of life stages, has achieved significant organized applications and advances in modes of intervention and tools.

The past two decades have witnessed waves of secularization with impacts of the concepts of spirituality and chaplaincy that diverged away from religion, more so in the UK and some European countries as compared to US applications. Spirituality became more generic and broad that revealed itself in helping and education of patients and families to earth and think of meaning and purpose of life, suffering death and dying.

The issues of spirituality and religiosity in the Islamic culture, teachings and attitudes towards patient care at terminal stages of life, is distinguished by clarity and harmony in view of clarity of Muslim beliefs and interpretations concerning purpose, meaning and mission of human life on this earth, end-of-life care and the afterlife.

This paper will address the contemporary western diverse concepts of spirituality, its relationship with religiosity in terminal patient care, and will elaborate on the holistic Islamic views and attitudes towards this stage of human life.

Keywords: End-of-life care, spirituality, religiosity, chaplaincy, Islamic end-of-life teachings.
\end{abstract}

International Journal of Human and Health Sciences Vol. 02 No. 02 April'18 Page : 65-70

\section{Introduction}

The past three decades have witnessed proliferation of interest in areas of palliative, spiritual and end of life care ${ }^{1}$. There is a wealth of literature on concepts of spirituality, religiosity, well-being, quality of life care and achieving a "good death". An extensive review of this topic ${ }^{1}$ has covered the English-language literature from 2000 to 2010, which included spiritual care at end of life settings, spiritual assessment tools and ongoing intervention modes, with the contributions coming from the professional disciplines of chaplaincy, nursing, social work, and interdisciplincy studies. Historically, a chaplain was seen as the representative of a particular faith, a clergyperson commissioned to provide pastoral services in institutions or governmental entities, which may include crisis management, counseling, worship, education, help in ethical decision making, staff support and church coordination ${ }^{2}$.

More recently, however, with the movement towards secularization, and the changes in definition of spirituality, the mission of chaplaincy has changed ${ }^{3}$.

Chaplains are no longer perceived as representing any particular faith or religion. They became responsible for spiritual care of people belonging to all faiths, and to those with no faith ${ }^{4,5}$. They focus on a generic form of spirituality, offered to a broad range of people with diverse beliefs ${ }^{5,6}$.

In the UK, and some other western countries, the concept of spirituality and spiritual needs is open for debate ${ }^{5,7}$.

Spirituality is perceived as a generic characteristic of human being, which reveals itself in search for meaning (of life, illness, death...etc.) ${ }^{8}$

Correspondence to: Wafa 'a Qasem Ahmad MD, Consultant Internist, Pain and Palliative Care Medicine, Ex-President- Palliative Care Society- Jordan, E-mail: wafaahmad192@gmail.com 
The Nursing profession and spiritual care:

The nursing profession has a long historical association with spirituality and religiosity ${ }^{9}$, with historical heritage of tending to patient suffering, emotions and spiritual needs of the sick, the dying and the destitute.

This spiritual heritage of nursing has gradually eroded in UK health care system run by the National Health Service (NHS), and expectedly in other western countries in the increasingly secular and materialistic societies, but survived in the context of charitable-run hospices ${ }^{10}$.

The concept and claims that spiritual patient care has therapeutic benefits, with enhancement of quality of life, there is pioneering work, educational and practice-oriented to support this previously unsubstantiated thinking ${ }^{11-13}$.

Research into spirituality has been extended to followers of various religions, ethnicities and culture denominations ${ }^{14,15}$.

\section{Social workers and spiritual care}

The first work looking at social work in end of life situations and bereavement was published in UK in $1997^{16}$. This national study revealed that majority of social workers acknowledge existential issues as significant.

In the UK, social work literature continues to distinguish psychosocial from spiritual care, in contrast to that in US ${ }^{17}$. There is an increasing use of the psychosocial-spiritual model for social work directed to people who are dying or bereaved ${ }^{18}$.

In many western countries, particularly in the UK, literature is more concerned with mental health and well-being ${ }^{19}$.

Some studies in older adults report on importance of religiosity and spirituality to mental health and well-being ${ }^{20}$, including the importance of belief for a "good death" 21 . A US study showed a range of practices such as yoga, prayers and meditation frequently used by some social workers. Western narratives which distinguish religion from spirituality, and develop a secular perspective ${ }^{22}$ are critiqued in the context of social work practice in multi-cultural settings, and the exporting of western models of education and practice to postcolonial contexts ${ }^{23}$.

On the other hand, study of older African Americans highlighted spiritual resources and strength of belief as the most significant factors in end of life decisions ${ }^{21}$.

Social workers were found to be more concerned with personal fulfillment and well-being, where chaplains focused on providing religious services and exploring psychological meanings ${ }^{24}$.

Social workers are often seen to take a "problem solving" approach ${ }^{25}$, where chaplains start from acceptance of mystery and paradox ${ }^{26}$.

\section{Spirituality and Religiosity}

Significant debates continued in the area of definition and exploring the relationship between spirituality and religion. The First Annual Report of the End of Life Care Strategy ${ }^{27}$ identified concerns that many of the available tools for the end of life care have been developed in the US, regarded as more religious than in the UK, and may not transfer well in the UK.

Spirituality is more generic, basic, and has wider implications than traditional religiosity ${ }^{28}$, it relates to the way in which people look at their lives, values, and perception of meaning and purpose of life, illness, wellbeing and death ${ }^{29,30}$. This renders spirituality as a diffuse term that is quite difficult to tie down ${ }^{31}$. The UK guidelines work to facilitate the needed environment for patients to die in the manner prescribed by their religion ${ }^{32}$. Religiosity is defined as participation in beliefs, rituals and activities of one of the traditional religions ${ }^{33}$. Religion is considered as a mode of spirituality, but both are not considered synonymous ${ }^{34}$.

Not all western writers agree on the benefits of religion within the context of end of life care ${ }^{35}$. On the other side, however, some experts consider religious spirituality to have clear benefits in the form of the coping with illness and impending death $^{36}$.

The significance of both religion and spirituality is in providing people with capabilities to make sense of their lives, to cope with their health experiences and suffering, and maintaining hope, inner harmony and peacefullness at this final days of suffering and challenges of life ${ }^{37}$.

In US literature, it is believed that religion and spirituality have positive impact on how patients perceive illness and end of life issues, and can be beneficial in terms of mental and physical health and well being ${ }^{38}$.

The raising of spiritual needs must come from the patient, rather than from the health care professional. Patients during their terminal times, may express their spiritual needs to talk about meanings of life, suffering and death.

In the UK literatures, a study showed most terminal patients expressed their top six spiritual needs, which are psychological in nature ${ }^{7}$ :

- To have time to think.

- To have hope. 
International Journal of Human and Health Sciences Vol. 02 No. 02 April'18

- To deal with unresolved issues.

- To prepare for death.

- To express true feelings without being judged.

- To speak of important relationships.

One of the required skills for health care professionals is to learn companioning and listening skills ${ }^{39}$ that focus on hearing the patient's spiritual dynamics, which reveal concerns and worries $^{40}$ :

- Being a burden on others.

- Abandoning loved ones.

- Regrets about unfinished duties and business.

- Fears of dying alone.

The carer becomes familiar with patients' needs in meditation, contemplation, and prayers that may bring them peace and well-being ${ }^{41,42}$.

Majority of patients would like their spiritual needs addressed by health care professionals, but this is not happening in practice ${ }^{43}$, in spite of the fact that spiritual care is a core component of palliative care ${ }^{44}$.

\section{Spirituality and Religiosity: Islamic attitudes} at the end of life

At the "end-of-life" stage, Islamic teachings and guidance are based on a set of foundational beliefs, as clearly outlined in Islamic original primary sources, namely: The Qur'an and the Prophetic Tradition (Sunnah) ${ }^{45}$. This guidance forms the basis of medical and spiritual care provided to patients and their families at this terminal stage of human life which is rampant with sufferings, fears, emotions and hopes.

The first cornerstone is the belief in the one God of all, the Creator of humans and Universe. Allah (the Arabic equivalent to God) Has the divine attributes of glory (Jalal), grace (Jamal) and immanence, yet He is loving, forgiving, merciful and very close to the human, even closer than his/ her jugular vein ${ }^{45,46}$ :

"We created the human being, and We know what his soul whispers to him. We are nearer to him than his jugular vein" "46.

The second concept: Allah (SWT) is the owner of everything and the ultimate of all. This concept implies that humans do not "own" their lives, health or wealth in the absolute sense ${ }^{45}$.

The Human body is a trust from Allah (SWT). The humans ownership is temporary, a trustee-type of ownership ${ }^{45}$.

The Qur'an states that Allah (SWT) created the human being to be His trustee on earth.
"Behold, thy Lord said to the angels: "I will create a vicegerent on earth." They said: "Wilt Thou place therein one who will make mischief therein and shed blood? - whilst we do celebrate Thy praises and glorify Thy holy (name)?" $\mathrm{He}$ said: "I know what ye know not."

This principle of trusteeship implies a trustee is not at full liberty to make life decision such as suicide or active euthanasia, or to unjustly behave in health and wealth decisions ${ }^{45}$.

The Qur'an is quite clear in answering universal questions pertaining to the human being, the human nature, mission on this earth, and where the human is going from here?

"Such is He, the Knower of all things, hidden and open, the Exalted (in power), the Merciful";"He Who has made everything which He has created most good: He began the creation of man with (nothing more than) clay", "And made his progeny from a quintessence of the nature of a fluid despised: "But He fashioned him in due proportion, and breathed into him something of His spirit. And He gave you (the faculties of) hearing and sight and feeling (and understanding): little thanks do ye give!"48.

Human Life, health, wealth and all resources available in this universe are means to help humans to fulfill that trust.

"And He has subjected to you, as from Him, all that is in the heavens and on earth: Behold, in that are Signs indeed for those who reflect" "49.

The Quryan states that Allah (SWT) Has created death and life, to test the human as to his/her conduct in this earthy life, which is but a temporary stage of human life. The real and eternal life is the life hereafter.

"Every soul shall have a taste of death: And only on the Day of Judgment shall you be paid your full recompense. Only he who is saved far from the Fire and admitted to the Garden will have attained the object (of Life): For the life of this world is but goods and chattels of deception" ".50.

"O my people! This life of the present is nothing but (temporary) convenience: It is the Hereafter that is the Home that will last" ${ }^{\prime \prime}$.

"He Who created Death and Life, that He may try which of you is best in deed: and He is the Exalted in Might, Oft-Forgiving;-"

The third central belief is the certainty of death, resurrection, the life hereafter, accountability before Allah (SWT), reward, forgiveness and punishment ${ }^{45}$.

The fact that everybody is going to die is absolutely 
certain, even to those who do not believe in God, or are unaware about the existence of $\operatorname{God}^{45}$.

Allah (SWT) predestines the moment and place of death for all. No one can delay or hasten his/her own death, or that of others.

"But to no soul will Allah grant respite when the time appointed (for it) has come; and Allah is well acquainted with (all) that ye do",53.

"Nor can a soul die except by Allah's leave, the term being fixed as by writing. If any do desire a reward in this life, We shall give it to him; and if any do desire a reward in the Hereafter, We shall give it to him. And swiftly shall We reward those that (serve us with) gratitude" 54 .

"To every people is a term appointed: when their term is reached, not an hour can they cause delay, nor (an hour) can they advance (it in anticipation) " 55 .

The Qur'an has vivid pictures of this eternal life in the hereafter:

"Whoever works righteousness, man or woman, and has Faith, verily, to him will We give a new Life, a life that is good and pure and We will bestow on such their reward according to the best of their actions" 56 .

"This will be) their cry therein: "Glory to Thee, O Allah." And "Peace" will be their greeting therein! And the close of their cry will be: "Praise be to Allah, the Cherisher and Sustainer of the worlds!" ${ }^{57}$.

"Their salutation on the Day they meet Him will be "Peace!"; and He has prepared for them a generous Reward" 58 .

Say: "O my Servants who have transgressed against their souls! Despair not of the Mercy of Allah. for Allah forgives all sins: for He is OftForgiving, Most Merciful" "s9.

This eternal life is glorified and distinguished by human dignity, forgiveness, purity, piece, love, harmony and complete absence of injustice or tyranny, as exemplified by many Qur'an verses:

"Then those who believe in Allah, and hold fast to Him, - soon will He admit them to mercy and grace from Himself, and guide them to Himself by a straightway" 60 .

"... We shall expel out of you all the evil in you, and admit you to a gate of great honour $\rangle^{61}$.

"That Day will every soul be requited for what it earned; no injustice will there be that Day, for Allah is Swift in taking account" 62 .

The Qur'an makes it clear that every soul shall taste death, including the greatest prophets. That in itself is a sort of consolation and alleviation of human fear of death, and of better coping in the critical times of suffering, grief and mourning ${ }^{45}$.

Muslim's beliefs of death and the afterlife has deep influence on patients and families' attitudes in consolation, harmonious/coping, and confidence of trust, belonging and connection to their Creator. "For them will be a home of peace in the presence of their Lord: He will be their friend, because they practiced (righteousness)" 63 .

"We are your protectors in this life and in the Hereafter: therein shall ye have all that your souls shall desire; therein shall ye have all that ye ask for!-" 64 .

A terminally ill patient who is used to performing his/her daily prayers and other acts of worship, including charity, is likely to pursue this conduct whenever and however possible, even during terminal illness, and feels more connected to his Creator with no intermediary ${ }^{45}$.

These times are appropriate to remember certain obligations and debts for other people and work to fulfill them, either directly or through his/her advance directive.

As for the rights and obligations toward Allah (SWT), there are many divine assurances to forgive and wave them after death of the believer. Say: "O my Servants who have transgressed against their souls! Despair not of the Mercy of Allah. for Allah forgives all sins: for He is OftForgiving, Most Merciful" 65 .

The medical practitioners and all concerned in caring and counseling of terminally ill patients have leading roles to provide caring and proper communication to alleviate distressing symptoms, fear, anxiety of patients and family members, guided the above holistic Islamic guidance.

\section{Conclusions}

Spiritual care has risen in health services over the last two decades, and became an integral part of health care systems across the world particularly so in palliative care at end of life care, towards patients, their families, and their carers. This review uncovered a substantial literature on spirituality and spiritual care at the end of life issues in Western countries reaching two main conclusions.

First, there is work to be done in applying conceptual debates and theoretical models with specific illustration on end of life care in practice. Second, there is a need for end of life care training programs at all levels to build knowledge and understanding (and by implication, confidence) in 
spiritual care, focusing on the rising objective of enabling more people to die at home (including care homes) for all, regardless of religion, belief, or affiliation.

On the other hand, the issues of spirituality and religiosity in the Islamic teachings and guidance towards patient's care at terminal stages of life is clearly outlined in the Islamic original primary sources namely: the Qur'an and the Prophetic
Tradition (Sunnah) as basis of medical and spiritual care, with clear fundamental concepts of faith and outlook towards life, death and the hereafter.

Following this holistic guidance, medical practitioners and all concerned in caring and counseling of terminally ill patients, are qualified to provide communications and vision in alleviating distress, fear, anxiety and emotions of patients and families.

\section{References}

1. Hollowing M, Adamson S, Me Sharry W, et al. spiritual Care at the End of Life: A systematic review of the literature. University of Hall-UK. www.dsh. gov.uk/publications

2. Hunter RJ. Dictionary of Care and Counselling, Nashville: Abingdon Press, 1990.

3. Mowat H, Swinton J. What do chaplains do? A report on a two year investigation into the nature of chaplaincy in the NHS in Scotland, Edinburgh: Scottish Executive, 2005.

4. Mowat H, Swinton J. What do chaplains do? The role of the Chaplain in meeting the Spiritual needs of patients, $2^{\text {nd }}$ Edition, Aberdeen: University of Aberdeen and Mowat Research, 2007.

5. Scotland NHS. Spiritual Care Matters An Introductory resource for all NHS Scotland Staff; Edinburgh: NHS Education for Scotland, 2009.

6. Spiritual Care Collaborative. Common Standards for Professional Chaplaincy Schaumburg, II: Spiritual Care Collaborative, 2004.

7. Stirling I. The provision of spiritual care in a hospice: moving towards a multidisciplinary perspective; Scottish journal of healthcare chaplaincy; 2007;10(2):21-26.

8. Association of Hospice and Palliative Care Chaplains (2006) Standards for Hospice and Palliative are chaplaincy $2^{\text {nd }}$ Edition, http://www.ahpcc.org.uk/pdf/ ahpccstandards2006.pfd, accessed 11.6.2010.

9. Bradshaw A. Lighting the lamp: the spiritual dimension of nursing care, London: Scutari Press, 1994.

10. Cobb M. The dying soul: Spiritual Care at the end of life, Buckingham: Open University Press, 2001.

11. Baldacchino D. Spiritual Care: Being in Doing, Preca Library: Malta, 2010.

12. Van Leeuwen $R$, Tiesinga LJ, Jochemasen $H$, Post D. "Aspects of spirituality concerning illness: Scandinavian Journal of Caring Science, 2007;21:482-519.

13. Van Leeuwen R, Tiesinger LJ, Middel B, Post D, Jochemsen $H$. "The effectiveness of an educational program for nursing students on developing competence in the provision of spiritual care", Journal of Clinical Nursing, 2008;17, 2768-2781. 
14. Garrad AR, Sheikh A. "Palliative care for Muslims and issues before death" International Journal of Palliative Nursing, 2006;8(11):526-531.

15. Chaaya M, Sibai AM, Fayad R, El-Roueheb Z. "Religiosity and depression in older people: evidence from underprivileged refugee and non refugee communities in Lebanon", Aging and Mental Heath, 2007;11(1):37-44.

16. Lloyd, M. (M. Holloway). "Dying and bereavement, spirituality and social work in the market economy of welfare", British Journal of Social Work, 1997;27(2):175-190.

17. Sheldon F. Psychosocial Palliative Care: Good practice in the care of the dying and bereaved, Cheltenham: Stanley Thornes, 1997.

18. Holloway M. Negotiating death in contemporary health and social care, Bristol: Policy Press, 2007a.

19. Coyte ME, Gilbert P, Nicholls V. Spirituality, Values and Mental Health: Jewels for the Journey, London: Jessica Kingsley, 2007.

20. Parker M, Roff LL, Klemmack DL, Koenig H, Baker P, Allamna RM. „Religiosity and mental health in southern community dwelling older adults', Aging and Mental Health, 2003;7(5),390-397.

21. Bullock K, McGraw SA, Blank K, Bradley EH. "What matters to older African Americans facing end of life decisions? A focus group study", Journal of social work in End of Life and Palliative Care, 2005;1(3):3-19.

22. Holloway M, Moss BH. Spirituality and Social work, Basingstoke: Palgrave MacMillan, 2010.

23. Wong YLR, Vinsky J. "Speaking from the margins: A critical reflection on the 'spiritual but no religious' discourse in Social Work", British Journal of Social Work, 2009;39:1343-1359.

24. Payne M. ' Social work practice identities: an agency study of a hospice', Practice, 2009;16(1):5-15.

25. Holloway M. "Spiritual Need and the Core Business of social work", British Journal of Social Work, 2007b;37(2):265-280.

26. Reese DJ, Sontage MA. "Successful inter professional collaboration on the hospice team", Health and Social Work, 2001;26(2), 167-175.

27. Department of Health. End of Life Care Strategy First annual report, London: DH Publications, 2009.

28. Marie Curie Cancer Care. Spiritual and Religious Care competencies for specialist palliative care, 2003, http://www.ahpcc.org.uk/pdf/spiritocomp.pdf, accessed 1.5.10.

29. National Consensus Project. Clinical Practice Guidelines for Quality Palliative care, $2^{\text {nd }}$ edition, Pittsburgh USA: National Consensus Project for Quality Palliative Care, 2009.

30. Puchalski C, Ferell B, Virani R, Otis-Green S, Baird P, Bull J, Chochinov H, Handzo G, Nelson-Becker H, Prince-Paul M, Pugliese K. "Improving the quality $\mathrm{f}$ spiritual care as a dimension of palliative care: the report of the consensus conference", Journal of Palliative Medicine, 2009;12(10):885-903.

31. Paley J. "Spirituality and nursing: a reductionist approach", Nursing Philosophy, 2008;9(1):3-18.
32. Department of Health. End of Life Care Strategy First annual report, London: DH Publications, 2009

33. NICE. Guidance on Caner Services: Improving Supportive and Palliative Care for Adults with cancer: The Manual, London: National Institute for Clinical Excellence, 2004.

34. Paley J. "Spirituality and secularization: nursing and the sociology of religion" Journal of Clinical Nursing, 2008;17(2):175-186.

35. Fillion L. Dupuis R, Tremblay I, De Grace GR, Breitbart W. "Enhancing meaning in palliative care practice: A meaning-centered intervention to promote job satisfaction", Palliative and Supportive care, 2006;4:333-334

36. Carroll B. "A phenomenological exploration of the nature of spirituality and spiritual care" Mortality, 2001;6(1):81-98.

37. Tarakeshwar N, Vanderwerker LC, Paulk E, Peare MJ, Stanislav VK, Prigerson HG. „Religious coping is associated with the Quality of Life of Patients with Advanced Nursing, 2006;39(5):500-509.

38. Johson LS. "Facilitating spiritual meaning-making for the individual with a diagnosis of terminal illness", counseling and values, 2003;47:230-240.

39. Puchalski CM. "Spirituality and End of Life Care: A time for listening and caring", Journal of Palliative Medicine, 2002;5(2):289-294.

40. Linberge DA. "Integrative Review of Research Related to Meditation, Spirituality and the Elderly", Geriatric Nursing, 2005;26(6):372-377.

41. Puchalski CM. "Spirituality and the care of patients at the end of life: an essential component of care: Omega,2007;56(1):33-46.

42. Yardley SJ, Walshe CE, Parr A. "Improving training in spiritual care: a qualitative study exploring patient perceptions of professional education requirements", Palliative Medicine, 2009;23:601-607.

43. Badawi G. Muslim Attitudes towards End-of-Life Decisions. Journal of the Islamic Medical Association of North America (JIMA), 2011 December 43(3): 134-139. Doi.5915/43-3-8602.

44. The Glorious Qur'an: 50:16.

45. The Glorious Qur'an: 2:30.

46. The Glorious Qur'an: 32:6-9.

47. The Glorious Qur'an, 45:13.

48. The Glorious Qur'an: 3:185.

49. The Glorious Qur'an: 40-39.

50. The Glorious Qur'an: 67:2.

51. The Glorious Qur'an: 63:11.

52. The Glorious Qursan: 3:145.

53. The Glorious Qur'an: 7:34.

54. The Glorious Qur'an: 16:97.

55. The Glorious Qur'an: 10:10

56. The Glorious Qur'an: 33:44.

57. The Glorious Qur'an: 39:53.

58. The Glorious Qur'an: 4:175.

59. The Glorious Qur'an: 4:31.

60. The Glorious Qur'an: 40:17.

61. The Glorious Qur'an: 6:127.

62. The Glorious Qur'an: 41:31

63. The Glorious Qur'an: 39:53. 